\title{
56. Three Faunal Provinces in the Early Cambrian Period
}

\author{
By Teiichi Kobayashi, M. J. A.
}

(Comm. April 12, 1972)

The Redlichia fauna in East and South Asia and Australia was so distinct from the Olenellina-bearing faunas in the rest of the world that their mutual relation has long been a moot question. Therefore Saito (1933) claimed that Redlichia would be early Middle Cambrian in age when he discovered Protolenus (i.e. Lusatiops (Coreolenus) coreanicus) below the Redlichia shales in North Korea. This age was later reiterated by King $(1937,1941)$ and emphasized by Öpik (1956). Mansuy (1912), Sun (1924), Saito (1936), Endo and Resser (1937), Whitehouse (1939) and many others including myself on the contrary supported Walcott's conclusion $(1905,1913)$ on the Lower Cambrian age of the Redlichia fauna. This chronology is now quite warranted by the coexistence of the Redlichiacea including Redlichia, Neoredlichia and Pararedlichia with the Olenellina in North Africa and North Asia on one hand and on the other by the find of such Olenellian eodiscids as Hebediscus and Dipharus in association with Redlichia in China.

Because our knowledge in the Cambrian geology became condensed toward the Atlantic side where the classical Acado-Baltic standard sequence had been founded, I have been trying to collect additional data in the Pacific side for many years to get a more comprehensive global concept. As the result I reached the conclusion that there were three major trilobite provinces with two subprovinces in each in the early Cambrian period (Kobayashi, 1952, 1971), as briefly described below.

1. The Redlichian province lacking the Olenellina.

a. East and South Asian subprovince where archaeocyathids are rare.

b. Australian-Antarctic subprovince where archaeocyathids are common.

2. The Intermediate province with the Redlichiacea, Ellipsocephalacea, Olenellina and archaeocyathids.

a. North Asiatic subprovince where the Corynexochida and Ptychopariida are common.

b. The Mediterranean subprovince where the Corynexochida and Ptychopariida are rare.

3. The Olenellian province lacking the Redlichiacea. 
a. Arcto-American subprovince where the Corynexochida and Ptychopariida are common. This is the most extensive subprovince comprising the North American region where archaeocyathids are wide spread and the Arctic-North Atlantic and Andine regions where they are rare or absent.

b. The Acado-Baltic subprovince in which the Corynexochida, Ptychopariida and archaeocyathids are rare.

The Redlichian province was widely separated from the ArctoAmerican subprovince by the Pacific basin.

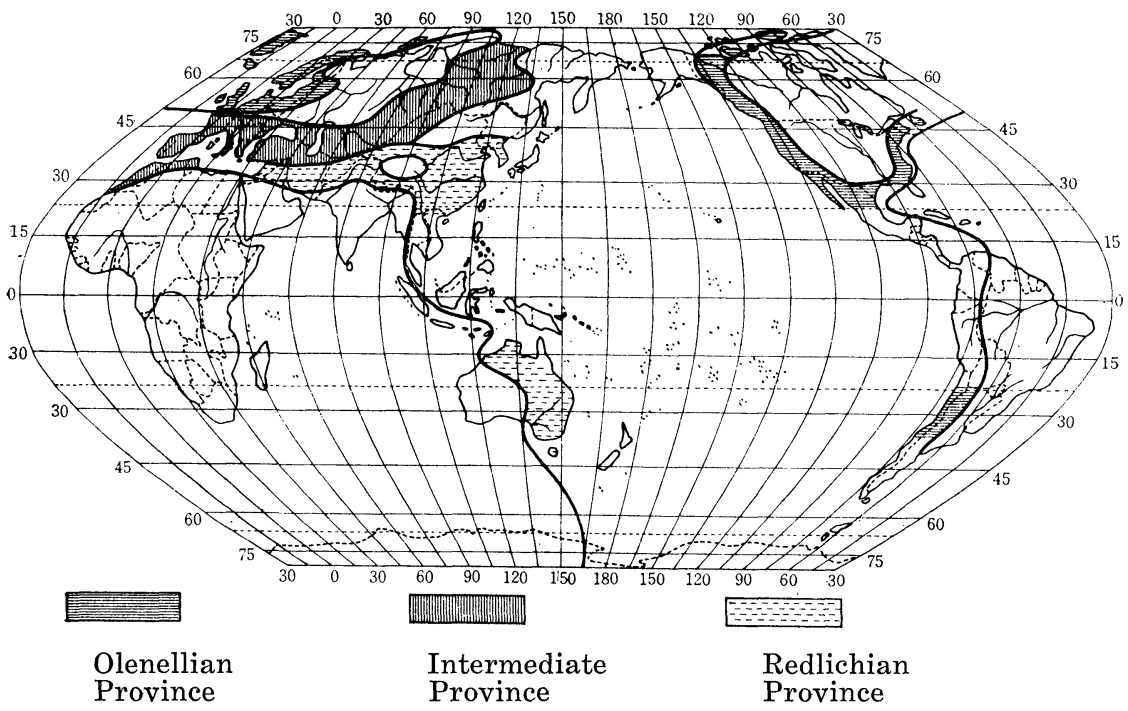

Figure showing the Three Early Cambrian Faunal Provinces.

For the correlation between the Redlichian and intermediate provinces Morocco in the west, Yunnan in the east and the SayanAltai mountains in the north are particularly important areas. In Morocco Pararedlichia and Neoredlichia occur respectively in the Fallotaspis tazemmourtensis zone in the lower and the DaguinaspisResserops zone in the upper part of the Amouslekian substage (Hupé, 1952, 1960) and in east Yunnan the former trilobite in the Eoredlichia zone of the Chiungchussu formation and the latter in the Redlichia chinensis zone of the Lungwangmiao formation (Chang, 1966).

In the Sayan-Altai mountains and the southern Siberian platform Hupeia and Redlichia occur respectively in the upper Aldanian and Botomian strata. Issafenian Resserops, Termierella and Micmac$c a$ are in the range from upper Aldanian to Botomian with their acme in the lower Botomian where they are accompanied by Redlichia, Palaeolenus and Hebediscus (Repina et al. 1964). 
For the correlation between the Olenellian and Intermediate provinces most important is the Wauboban sequence of the Inyo mountains, California (Nelson and Hupé, 1964) as follows:-

II. Upper Series: Silver Peak group with archaeocyathids and olenellids.

2. Harkless formation containing the first Olenellus.

1. Poleta formation containing Nevadia and abundant archaeocyathids.

I. Lower series.

3. Campito quartzitic sandstone with siltstone intercalations.

b. Montenegro member with Fallotaspis longa, Daguinaspis, Nevadia, Holmia and archaeocuyathids in the upper part.

a. Andrews mountain member with Fallotaspis tazemmourtensis.

2. Deep Spring limestone and quartzite.

1. Red dolomite, partly oolitic, containing doubtful algae.

Some genera of trilobites are common between the Lower Cambrian faunas of Morocco and North Asia. For example,

Fallotaspis ranging from Amouslekian to Timighitian is reported from the lower Aldanian (Elgyan) horizon.

Hebediscus, a lower Timighitian member in Morocco ranges from upper Aldanian to lower Botomian.

Resserops, a middle Tasousekhtian genus in Morocco occurs in the middle lower Botomian in South Siberia.

Table I

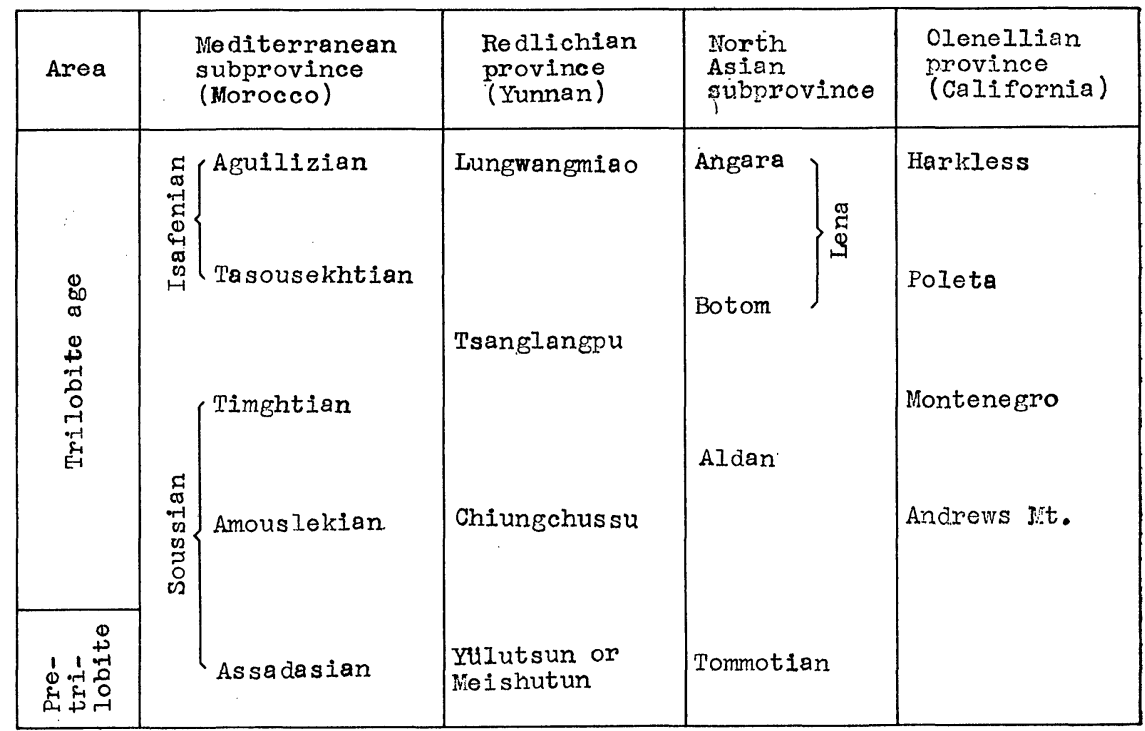


Pagetiellus, another middle Tasousekhtian genus, ranges down to middle Aldanian from Botomian in South Siberia.

Thus, there are some homotaxism between the two subprovinces. The Lower Cambrian formations of the three provinces are, however, tentatively correlated as shown in Table I.

It is noteworthy that the so-called Tethys of the early Cambrian age was by no means a simple monotonous faunal province (Sdzuy, 1967). In the west it revealed the Mediterranean subprovince which was tied up with the North Asiatic subprovince through the Dead Sea (Parnes, 1971) and probably through Caucasus where archaeocyathids occur. The Tethyan zone to the east of Iran on the contrary belongs to the Redlichian province.

Cowie (1971) recognized two realms in addition to two provinces in the early Cambrian palaeogeography as follows:

I. Olenellid realm.

a. Acado-Baltic province (European, Atlantic or North Atlantic).

b. Pacific province (American).

II. Redlichiid realm (Australia, Indochina, China, Korea, Manchuria, central, eastern and arctic Siberia, Iran, Jordan, Sardinia, Morocco, northern Mauritania (West Africa) and probably Antarctica).

His Pacific province is better to say the Arcto-American province. This province was separated from the Acado-Baltic province by the Caledonian axis, like the Hwangho and Yangtze basins in Eastern

Table II

\begin{tabular}{|c|c|c|c|}
\hline \multicolumn{2}{|c|}{ T. Kobayashi } & \multirow{2}{*}{\multicolumn{2}{|c|}{$\begin{array}{l}\text { Cowie } \\
1971\end{array}$}} \\
\hline \multirow{2}{*}{\begin{tabular}{|r|}
1952 \\
Frovince
\end{tabular}} & \multirow{2}{*}{$\frac{1971}{\text { Subprovince }}$} & & \\
\hline & & Province & Realm \\
\hline \multirow{2}{*}{ Redlichian } & East \& South Asian & \multirow{4}{*}{ (Undivided) } & \multirow{4}{*}{ Redlichiid } \\
\hline & Australo-Antarctic & & \\
\hline \multirow{3}{*}{ Intermediate } & North Asian & & \\
\hline & & & \\
\hline & & \multirow{2}{*}{ Acado-Baltic } & \multirow{3}{*}{ Olenellid } \\
\hline \multirow{2}{*}{ Olenellian } & Acado-Baltic & & \\
\hline & Arcto-American & Pacific & \\
\hline
\end{tabular}


Asia by the Tsinling axis (Kobayashi, 1967). It is quite confusing that the Acado-Baltic province is extended as far as North Africa in a way, while the Mediterranean region is referred to the Redlichiid realm in another way. In my opinion the three faunal provinces proposed in 1952 are the major units of the Cambrian palaeogeography and the Acado-Baltic subprovince which was separated from the Mediterranean subprovince by the Variscan axis in Central Europe would be a small area of the Olenellian province in comparison with the vast Arcto-American subprovince. (See Table II.)

Which one of the three provinces is incipient? Which is the oldest trilobite horizon in the three provinces? These are two problems left in future. In view of the fact that the Fallotaspis tazemourtensis zone or horizon in Morocco and California is nearly contemporaneous with the Eoredlichia zone in Yunnan and the Fallotaspidella horizon of North Asia, I think that the three faunal provinces have already been existed at about the beginning of the trilobite age, the fact suggesting that naked trilobites must have been near the end of the pre-trilobite age.

Finally, I call attention to the fact that the intermediate province where the archaeocyathids which are considered warm water inhabitants have greatly thrived, was clearly bisected into the North Asian and Mediterranean subprovinces by the early Cambrian palaeoequator deduced by palaeomagnetism. (See Fig. 2, in Cowie, 1971.)

Selected References.

The reader is referred to Bibliographies in Kobayashi (1967, 1971).

\section{References}

Chang, W. T. (1966): On the classification of redlichiacea with description of new families and new genera. Acta Pal. Sinica, 14, No. 2, p. 135-184.

Cowie, J. W. (1971): Lower cambrian faunal provinces. Faunal provinces in space and time, p. 31-46. Geol. Jour. Sp. Issue, No. 4. Liverpool.

Hupé, P. (1960): Sur le Cambrien inférieur du Maroc. Intern. Geol. Congr. Rep. XXI, Sess. Norden, 1960, Pt. 8, p. 75-85.

Kobayashi, T. (1952) : Cambrian Period. Historical Geology, 1, p. 85-106. Asakura Book Co. Tokyo.

(1967): The Cambrian of Eastern Asia and other parts of the continent.

The Cambro-Ordovician formations and faunas of South Korea, Pt. X, Sec. C. Jour. Fac. Sci. Univ. Tokyo, Sec. 2, 16, Pt. 3, p. 381-534.

- (1971): The Cambro-Ordovician faunal provinces and the interprovincial correlation. The Cambro-Ordovician Formations etc. Part X, Sec. E. Ibid., 18, No. 1, p. 129-299.

Nelson, C. A., and Hupé, P. (1964) : Sur l'existence de la Fallotaspis et Duguinaspis, trilobites marocaines, dans le Cambrien inférieur de Californie et ses 
consequences. Acad. Sci. Paris, C. R. t, 258, Gr. 9, p. 621-623.

Parnes, A. (1971): Late Lower Cambrian Trilobites from Timna area and Har 'Amram (Southern Negev, Israel). Israel Jour. Earth-Sciences, 20, p. 179-205.

Repina, L. N., Khomentovskii, V. V., Zhuravleva, I. P., and Rozanov, A. Y. (1964) : Biostratigraphy of the Lower Cambrian in the Altai-Sayan Folded district, $364 \mathrm{pp}$. Acad. Sci. USSR, Siberian Branch, Inst. Geology and Geophysics.

Saito, K. (1933): On the occurrence of Protolenus in the Cambrian rocks of North Korea. Japan. Jour. Geol. Geogr., 10, p. 145-151.

Sdzuy, K. (1967) : The Tethys in Cambrian Time. Aspects of Tethyan Biogeography, p. 5-9. Systematics Ass. Publ. No. 7. 